\title{
AS MULHERES ENTRAM EM CAMPO? A COBERTURA DO JORNAL GAZETA DO POVO REFERENTE ÀS COPAS DO MUNDO DE FUTEBOL FEMININO DOS ANOS DE 2007 E 2015
}

\section{WOMEN ENTER THE FIELD? THE COVER OF THE NEWSPAPER GAZETA DO POVO REFERRING TO THE WOMEN'S WORLD CUP OF THE YEARS 2007 AND 2015}

\author{
Nathalia Lutt Lourenço* \\ Dayanne Vieira Santos Pinto ${ }^{* *}$ \\ Fabiana Della Giustina dos Reis ${ }^{* * *}$ \\ Maria Thereza Oliveira Souza ${ }^{* * * *}$ \\ André Mendes Capraro ${ }^{* * * * *}$
}

\section{RESUMO}

Essa pesquisa busca investigar o histórico recente de aparição do futebol feminino no jornal impresso Gazeta do Povo. Para tanto, delimitou sua cobertura das edições da Copa do Mundo dos anos de 2007 e 2015, buscando demonstrar e problematizar a forma e a recorrência de reportagens sobre tais eventos e, perceber se há um crescente interesse por essa modalidade feminina ou se a situação de pequena repercussão é uma constante. Foi constatado que, nesses anos, o jornal não realizou uma cobertura que promovesse a competição, e que, mesmo durante sua realização, nenhuma chamada foi publicada na capa do periódico. Conclui-se que o aparecimento do futebol feminino na mídia segue um padrão de descontinuidade, já que isso geralmente ocorre apenas em períodos específicos e ainda depende de bons resultados da seleção brasileira para uma vinculação maior de notícias.

Palavras-chave: Futebol Feminino; Gazeta do Povo; Copa do Mundo; Jornal.

\begin{abstract}
This research seeks to investigate the recent history of the appearance of women's soccer in the printed newspaper Gazeta do Povo. In order to do so, it delimited its coverage of the World Cup editions of the years 2007 and 2015, seeking to demonstrate and problematize the form and the recurrence of reports about such events and to see if there is a growing interest in this feminine modality or if the situation of small repercussion is a constant. It was found that, in those years, the newspaper did not promote the competition, and even during its execution, no calls were published on the cover of the newspaper. It is concluded that the appearance of women's soccer in the media follows a pattern of discontinuity,
\end{abstract}

"Graduada (Bacharelado) e Mestranda em Educação Física na Universidade Federal do Paraná.

** Graduada (Bacharelado e Licenciatura) em Educação Física na Universidade Federal do Paraná. Professora de Educação Física no Colégio Positivo.

${ }^{* * *}$ Graduada (Bacharelado) e Mestranda em Educação Física na Universidade Federal do Paraná.

${ }^{* * * * *}$ Mestre e Doutoranda em Educação Física na Universidade Federal do Paraná. Professora de Educação Física no Centro Universitário Campos de Andrade.

***** Doutor em História na Universidade Federal do Paraná. Estágio Pós-doutoral na Università Ca’ Foscari di Venezia. Professor de Educação Física na Universidade Federal do Paraná. 
since this usually occurs only in specific periods and depends on the good results of the Brazilian team for a greater linkage of news.

Key Words: Women's Soccer; Gazeta do Povo; World Cup; Newspaper.

\section{INTRODUÇÃO}

A organização de torneios mundiais de futebol feminino ainda tem história bastante recente, pelo menos no que concerne às realizações da entidade que hoje regulamenta a modalidade - FIFA (Fédération Internationale de Football Association). A federação elaborou o primeiro mundial da categoria em um momento em que o futebol feminino, principalmente no Brasil, tinha pouquíssima aderência, o que tornou as fases preliminares um tanto confusas e sem um padrão organizado de competição, assim:

[...] com a realização da I Copa do Mundo oficial, a atividade futebolística feminina no Brasil resumirse-ia, basicamente, a seleção nacional. Como o subcampo futebolístico feminino estava em processo de estruturação, as suas lógicas de funcionamento específicas não estavam definidas. Por conseguinte, a Confederação Sul-Americana de Futebol (CONMEBOL) organizou o I Sul-Americano, realizado no Brasil, em Maringá, entre os dias 28 de abril e 5 de maio de 1991, regulamentando-o como classificatória direta e única para o Mundial. (GABRIEL, 2014, p. 154).

No mesmo ano, então, sob esse contexto ainda bem amador no modelo de organização e competição, aconteceu a primeira edição da Copa do Mundo de Futebol Feminino, na cidade de Guangzhou - China. As finalistas foram as seleções dos Estados Unidos e da Noruega. O jogo decisivo terminou 2x1, sagrando as americanas como as primeiras campeãs mundiais de futebol feminino (SILVA, 2015).

$\mathrm{O}$ acontecimento do primeiro Mundial se deu principalmente por uma iniciativa tomada em 1988, pelo então presidente da FIFA, João Havelange, em promover o "Torneio Internacional de Futebol Feminino". Esse torneio foi uma espécie de teste para a possível realização do Mundial (FONTES JUNIOR, 2015).

Com um público de 35 mil pessoas, a Noruega sagrou-se campeã diante da Suécia. A equipe brasileira chegou na terceira colocação, vencendo a China nos pênaltis. Com o sucesso da competição, três anos depois, as atenções voltaram-se para a China, desta vez para a primeira Copa do Mundo de Futebol Feminino da história. Contando com 45 seleções nas Eliminatórias, o torneio teria a presença de 12 seleções de 6 confederações diferentes, novamente com o Brasil entre as equipes. A competição foi sediada em 4 cidades, tendo 6 estádios recebendo partidas do torneio (FONTES JUNIOR, 2015).

A partir de seu primórdio, então, já foram realizadas mais seis edições da Copa do Mundo de futebol feminino. Em 1995, ocorreu a segunda edição do Mundial, que foi sediado na Suécia e a grande campeã foi a seleção da Noruega que derrotou as alemãs no jogo derradeiro. Em 1999, com sede nos Estados Unidos, as americanas se tornaram bicampeãs mundiais. Em 2003 o mundial ocorreu na China, mas devido a uma epidemia da gripe aviária transferiram o local para os EUA. Neste ano, as alemãs conquistarem o título mundial sobre as suecas.

O torneio de 2007 foi realizado na China e contou com a participação de 15 países, sendo eles: Nigéria, Gana, China, Austrália, Coreia do Norte, Japão, Estados Unidos, Canadá, Noruega, Suécia, Alemanha, Dinamarca, Inglaterra, Nova Zelândia, Argentina e Brasil. Tal escolha foi feita em decorrência da efetiva participação do selecionado brasileiro, já que as atletas chegaram à final do torneio e só foram derrotadas pela forte seleção alemã. Antes disso, sua trajetória incluiu a primeira colocação do grupo D, no qual somou três vitórias em três jogos contra as seleções da China, Dinamarca e Nova Zelândia. Nas quartas de final o Brasil enfrentou a Austrália, segunda colocada do grupo $\mathrm{C}$, e venceu por $3 \times 2$. Já na fase de semifinal, as brasileiras enfrentaram as norte-americanas, e com o placar elástico de $4 \mathrm{x} 0$ e memorável atuação da então melhor jogadora do mundo, Marta, garantiram a vaga para a final. Como já mencionado, a seleção alemã derrotou a brasileira e pelo placar de 2x0, sagrando-se nessa oportunidade bicampeãs mundiais. Apesar da derrota, o resultado de certa maneira foi histórico para as brasileiras, já que foi 
a melhor colocação conquistada até hoje pelo Brasil nos mundiais de futebol feminino. Além da medalha de prata, Marta, camisa 10 da seleção brasileira, marcou sete gols no mundial e conquistou os prémios de Bola de Ouro Adidas (prêmio para a melhor atleta da competição) e Chuteira de Ouro Adidas (prêmio para artilheira da competição). Pela primeira vez na história da Copa do Mundo de Futebol Feminino, todas as equipes participantes receberam prêmios em dinheiro, contabilizados em dólares. De acordo com a FIFA, a seleção campeã recebeu 1.000.000, a vice-campeã 800.000 , a terceira colocada 650.000 , a quarta 550.000, aquelas seleções que chegaram até as quartas de final receberam uma quantia de $300.000 \mathrm{e}$ as que ficaram na fase de grupos, 200.000.

Em 2011, a Copa do Mundo aconteceu na Alemanha, e foi a vez do Japão conquistar pela primeira vez o título de campeão mundial, vencendo os EUA nos pênaltis por $3 \times 1$, após um empate em $2 \times 2$ no período normal de jogo.

Na última edição do mundial, em 2015, realizada no Canadá, o número de equipes participantes aumentou de 16 para 24 seleções, sendo que 8 nunca tinham participado dessa competição até então. As seleções que participaram foram Nigéria, China, Austrália, Coréia do Sul, Japão, Tailândia, México, Estados Unidos, Canadá, Costa Rica, Noruega, Suécia, Suíça, Alemanha, Inglaterra, Espanha, Países Baixos, França, Nova Zelândia, Brasil, Colômbia, Equador, Camarões e Costa do Marfim. O Brasil foi eliminado pela Austrália nas oitavas de final do torneio.

A próxima edição da Copa do Mundo será disputada em 2019 na França e, por enquanto, as informações são escassas e muitas pessoas não sabem da sua realização. Em contrapartida, a modo de exemplo, a última Copa do Mundo masculina ocorreu entre os meses de junho e julho de 2018, na Rússia, e o engajamento midiático e populacional foi bastante claro. Todos os jogos da competição foram transmitidos pelo principal canal de TV a cabo do país e o canal aberto que dispunha dos direitos de transmissão apenas não passou ao vivo os jogos que tiveram sobreposição de horários com outros, na última rodada da fase de grupos. Esse engajamento pôde ser percebido muito antes da realização do evento, sendo um exemplo disso a "contagem regressiva" feita em diversos meios de comunicação quando faltava um ano para o início do torneio.
Tal pesquisa se interessa então por investigar o histórico recente de aparição do futebol feminino na mídia impressa brasileira. Para tanto, delimitou o jornal Gazeta do Povo e sua cobertura das edições femininas da Copa do Mundo dos anos de 2007 e 2015, no intuito de demonstrar e problematizar a forma e a recorrência de reportagens sobre tais eventos e, então, perceber se há um crescente interesse por essa modalidade feminina ou se a situação de pequena repercussão é uma constante. Tais edições foram escolhidas a partir dos seguintes critérios: 2007 por ter sido a melhor colocação brasileira em copas do mundo e 2015 por ser aquela de realização mais recente. Já por isso a anterior descrição mais detalhada dessas duas edições.

\section{METODOLOGIA}

No sentido de atingir o objetivo lançado anteriormente, buscou-se respaldo da metodologia de análise de fontes jornalísticas. Para analisar um jornal e seu conteúdo, devemos pensar, então, qual a posição social ocupada pelo periódico. Pensar, no caso específico do presente estudo, quais são aqueles assuntos mais usualmente noticiados no caderno esportivo da Gazeta do Povo.

O próprio nome dos periódicos já pode fornecer questões para análise. Neste caso, o nome Gazeta do Povo parece remeter a uma tentativa de aproximação com o leitor, já que o termo "do Povo" passa a impressão de pertencimento e apropriação por parte do público leitor. O jornal possui um enfoque principal nas informações locais e regionais. De acordo com Silva (2015), a Gazeta possui aproximadamente 90 anos e é fruto de um projeto de duas famílias tradicionais de Curitiba, sendo, atualmente, integrante do grupo GRPcom, que é o principal grupo de comunicação do estado do Paraná. Vale lembrar que a Gazeta também está disponível na internet, através da Gazeta do Povo online, mas que para o presente trabalho foram utilizadas apenas versões impressas.

A partir da compreensão da já citada predominância de assuntos locais e regionais no conteúdo vinculado pelo periódico analisado, tornase facilmente visualizável a grande preferência dada à veiculação de reportagens referentes aos três principais clubes de futebol da capital paranaense (Coritiba, Atlético Paranaense e Paraná Clube) 
no seu caderno esportivo. As páginas destinadas à discussão esportiva possuem na grande maioria dos dias um amplo espaço destinado a tratar de questões cotidianas, de preparação ou de resultados obtidos pelos três clubes mais representativos do estado. Não raro, existem também grandes chamadas relacionadas a isso na própria capa do jornal, além de colunas e charges destinadas a repercutir fatos interessantes sobre ambos.

Levando em consideração a parcialidade da veiculação de notícias pelos jornais, torna-se ainda mais necessária a avaliação dos objetivos e escopo do periódico que se pretende analisar. Sabe-se também que, para uma informação ser noticiada em um jornal, existem critérios que devem ser levados em consideração. "Primeiramente são avaliados os critérios de noticiabilididade, ou seja, os elementos que tornam uma informação notícia, tais critérios estão relacionados com novidade, relevância e alcance de público" (SILVA, 2015, p. 227).

Sendo assim, a mídia impressa, que diferentemente da televisiva, não conta com o tempo de comerciais e propagandas, possui algumas formas de dar destaque para determinadas informações. Uma delas é trazer nota de uma matéria para a capa do jornal, a qual, normalmente, gera um primeiro impacto no leitor, com o objetivo de despertar a curiosidade para ler a matéria completa que estará dentro dos cadernos. Outra forma de salientar ou dar importância a uma notícia é através do espaço físico ocupado por essa matéria no jornal, isso é determinado de acordo com o interesse do público em determinado conteúdo, ou de acordo com o diagnóstico de importância dado pelo jornalista a essa matéria. Levar em conta esses mecanismos é de essencial necessidade, então, para o presente estudo, já que a avaliação do discurso midiático do específico periódico analisado acerca do objeto de estudo deverá passar necessariamente por esse tipo de crivo (LUCA, 2008).

Além disso, para analisar esse tipo de fonte é necessário fazer uma especificação temporal. Sendo assim, como já foi dito anteriormente, os anos dos mundiais que foram analisados são os de 2007 e 2015. Em relação às reportagens recortadas, foram feitas análises do mês que antecedeu a competição, do mês em que ocorreu a Copa e o mês que sucedeu o campeonato. Em 2007, o mundial aconteceu entre os dias 10 e 30 de setembro. Portanto, as reportagens analisadas foram as publicadas nos meses de agosto, setembro e outubro. Já em 2015, no Canadá, a Copa do Mundo aconteceu entre os dias 6 de junho e 5 de julho. Desse modo, as reportagens analisadas foram as publicadas em maio, junho e julho.

\section{A COPA DO MUNDO DE 2007: O RETRATO DA GAZETA DO POVO}

A Copa do Mundo de futebol feminino de 2007, realizada entre os dias 10 e 30 de setembro, foi reportada pelo jornal Gazeta do Povo em vinte e oito (28) oportunidades.

Durante o período de realização do referido campeonato, os jogos considerados importantes pela edição do periódico foram citados no espaço "Programe-se", do caderno esportivo da Gazeta. O quadro configurava-se como aviso para aqueles eventos de maior importância do mundo esportivo na semana. Quando esses eventos aconteceriam no dia de publicação do jornal, as partidas eram destacadas no espaço "Hoje na TV", o qual detalhava o horário e os canais que transmitiriam os mesmos. Alguns desses avisos contavam com uma nota um pouco maior para detalhar informações mais precisas sobre o evento. Sendo que, as oportunidades nas quais foram encontradas essa especificidade relacionada à Copa do Mundo de Futebol Feminino daquele ano, serão identificadas na sequência.

A cobertura do evento mundial na Gazeta começa inclusive com uma dessas notas. No dia 11 de setembro de 2007, um dia após a abertura da competição, o jornal trouxe, no quadro "Programase", a seguinte nota: "atual campeã Pan-americana, a seleção estreia como uma das favoritas ao título da competição" (GAZETA DO POVO, 11 de set. 2007, p. 2 - caderno esportivo). A notícia contou também com uma pequena foto sobre a antecedente abertura.

A primeira grande matéria sobre a Copa do Mundo de 2007 foi publicada no dia 11 de setembro, na página três do caderno esportivo. Cheia de detalhes sobre a competição, a reportagem contava com informações sobre a quantidade de times participantes do evento, a cidade em que aconteceria o jogo de estreia da seleção brasileira, além de suas primeiras adversárias. O jornal deu grande destaque para a jogadora Marta, publicando um trecho de uma entrevista feita com a jogadora e vinculando, 
inclusive, uma imagem de jornalistas chineses cercando a camisa 10 do Brasil. Além disso, na mesma matéria, o jogo entre Alemanha e Argentina, que teve um placar de 11 a 0 para as alemãs, foi citado como "a partida com o maior número de gols em partidas realizadas pela FIFA, incluindo jogos de homens e mulheres" (GAZETA DO POVO, 2007, p. 2 - caderno esportivo). Há, ainda, mais uma nota sobre a citada goleada alemã, logo abaixo da matéria anterior, possuindo também uma imagem ilustrativa sobre o jogo, fato que demonstra a importância dada ao feito da equipe europeia.

O grande destaque da matéria "Tudo igual" (Gazeta do Povo, 12 set. 2007, p.2 - caderno esportivo), veiculado no dia 12 de setembro, foi a imagem ilustrativa da nota trazida pelo jornal. A foto possuía tamanho considerável e que provavelmente chamou a atenção do público para ler e entender melhor do que se tratava tal ilustração, que tinha a atacante inglesa Kelly Smitt beijando sua chuteira. A nota presente abaixo da foto informava sobre os placares dos jogos que haviam ocorrido no dia anterior, além de apresentar aqueles que iriam acontecer no dia seguinte.

No espaço "Programe-se", do dia 12 de setembro, abaixo da informação que continha o horário do confronto entre Nova Zelândia e Brasil, foi escrita uma pequena nota: "A equipe nacional, atual campeã pan-americana, aposta tudo no talento da armadora Marta" (GAZETA DO POVO, 12 set. 2007, p.2 - caderno esportivo). Aqui se evidencia um possível motivo para uma maior cobertura que estava sendo dada até então ao selecionado nacional: a recente conquista do título pan-americano e a grande aposta no talento da jogadora Marta, que teve uma foto sua ilustrando esse espaço no jornal.

O fato é que, como já citado, as brasileiras haviam conquistado um título continental disputado no Brasil, no qual a grande final ocorreu frente a um Maracanã preenchido por aproximadamente 50 mil pessoas. Com isso, as atletas adquiriram certa legitimidade para reclamar por melhores condições para o esporte no país, o que gerou uma momentânea fluência de informações.

No dia 15 de setembro, o periódico publicou uma nota referente ao jogo entre a seleção brasileira e a chinesa, que seria válido pela segunda rodada da primeira fase daquela Copa do Mundo. Seu conteúdo focava na provável pressão que a equipe brasileira sofreria da torcida adversária, já que estaria enfrentando a anfitriã da competição. Posterior ao jogo, que terminou com vitória brasileira por 4 a 0 , a matéria publicada pelo jornal deu destaque para algumas qualidades técnicas da seleção, principalmente ao talento individual das jogadoras Marta e Cristiane. Além disso, informou-se que a seleção brasileira mantinha seu aproveitamento de $100 \%$ ao vencer as duas primeiras partidas da competição e a defesa menos vazada desta.

No dia 21 de setembro, a partida entre Brasil e Dinamarca, que havia acontecido no dia anterior (20), recebeu um considerável destaque nas páginas do caderno esportivo da Gazeta. Além de contar com um grande espaço físico, a matéria também possuía uma imagem sobre a vitória da seleção brasileira. No transcorrer da notícia, detalhes sobre a partida foram sendo citados, principalmente, com relação a pouca efetividade da seleção brasileira no ataque e a baixa qualidade técnica apresentada. Somou-se a isso a informação da grande quantidade de finalizações que a seleção alemã, responsável por uma goleada de 11 a 0 na seleção argentina, vinha tendo na competição. Por fim, a reportagem contou com um excerto de fala do técnico da seleção dinamarquesa: "É suicídio jogar contra o Brasil sem uma defesa reforçada. É como se fosse declarar para o mundo inteiro 'quero perder"' (MOLLER, Gazeta do povo, 21 set. 2007, p.3 - caderno esportivo). Todos esses fatores salientados parecem se juntar em maneira de cobrança por um desempenho melhor da seleção nos próximos jogos, já que as atletas tinham qualidade técnica suficiente para tal, e de fato teriam que o fazer se quisessem se aproximar da bela performance alemã até ali. Com relação ao papel do periódico, já parece haver um aumento do espaço dado ao selecionado nacional, já que antes mesmo da realização do jogo citado, haviam sido divulgados três matérias em dias anteriores, no intuito de divulgar o confronto, ora em forma de lembrete de transmissão, ora com detalhes técnicos sobre este.

Outro indício de uma maior abertura para a campanha brasileira na Copa do Mundo de 2007 foi o grande espaço dedicado à promoção do confronto válido pelas quartas de final da competição, no qual a seleção brasileira iria enfrentar a Austrália. A reportagem foi veiculada no dia 23 de setembro, 
além de destacar a melhor campanha que a equipe conquistou na primeira fase da competição, contava com trechos de entrevista de um dos símbolos do futebol feminino no Brasil, a atleta Formiga, que iniciou dizendo: "Tenho 16 anos de seleção, disputei 4 mundiais e com certeza essa é a equipe mais forte que tivemos. São boas as possibilidades de chegarmos a final" (GAZETA DO POVO, 23 set. 2007, p.5). Sobre a medalha de prata nas Olimpíadas de Atenas em 2004, a atleta comentou: "Foi um dos momentos mais especiais da minha carreira" (GAZETA DO POVO, 23 set. 2007, p.5). Com relação à reta final da Copa do Mundo, Formiga afirmou: "Não podemos escolher os adversários até a grande decisão. Temos que encarar quem vier, ditando nosso ritmo de jogo e melhorando certos detalhes. Por exemplo: precisamos trabalhar o último passe antes da finalização" (GAZETA DO POVO, 23 set. 2007, p.5).

A cobertura continua com mais uma reportagem detalhada sobre a participação da seleção brasileira na Copa do Mundo. Dessa vez reportando o jogo entre Brasil e Austrália, válido pelas quartas de finais, a reportagem descreveu aspectos técnicos e detalhou os lances mais importantes do confronto decisivo, trazendo, inclusive, uma imagem que ilustrava o momento de comemoração de um dos gols convertidos pela seleção brasileira, na partida que terminou em 3 a 2 para o Brasil.

Seguindo o mesmo padrão de publicações, entre o dia em que o Brasil venceu as australianas, nas quartas de finais, e o dia em que iria acontecer o confronto entre Brasil e EUA - 23 e 26 de setembro, respectivamente -, houve sete menções à participação da seleção brasileira no mundial; da quais, três matérias eram detalhadas, outras três foram publicadas no "Programe-se" e uma no "Hoje na TV". O foco principal de todas essas vinculações era salientar a importância do confronto que estava por vir, já que este era válido pela semifinal da Copa do Mundo e as adversárias eram as então atuais campeãs olímpicas (Atenas, 2004), que haviam inclusive derrotado a seleção brasileira nessa competição. Além disso, era a chance de se chegar a uma inédita final de campeonato mundial.

O jornal privilegiava as informações sobre os jogos das brasileiras, mas no dia 26 , foi publicada a primeira matéria sobre o mundial com relação a outras equipes, já que o confronto citado valeria a outra vaga para a final da competição - Alemanha e Noruega. Nessa reportagem, foram destacadas as principais características das duas seleções envolvidas na citada semifinal e a previsão de que seria um jogo de ataque contra defesa, em virtude da campanha desses times na competição - já que a Alemanha possuía o ataque mais eficiente e a Noruega, a defesa menos vazada.

A segunda matéria, com um enfoque na jogadora Marta, tratava do respeito e reconhecimento das americanas quanto ao futebol da artilheira da seleção brasileira. Reconhecimento este, que foi demonstrado através da publicação de um trecho de uma entrevista realizada com as atletas dos EUA:

Eu espero um jogo muito físico, como foi o amistoso em junho [2 a 0 EUA]. Marta não estava lá, mas ela é uma das mais talentosas jogadoras do mundo. Sua presença em campo irá deixar o time do Brasil muito melhor no ataque (GAZETA DO POVO, 26 set. 2007, p. 2 do caderno esportivo).

Além de divulgar o confronto, a matéria, ao destacar a preocupação das americanas com a habilidade da Marta, provavelmente tinha a intenção de promover o confronto pautado sobre a imagem simbólica que essa atleta já havia conquistado.

No dia 28 de setembro, a matéria que detalhava o jogo, que resultou na primeira disputa de final das brasileiras, ocupou uma página completa do caderno esportivo da Gazeta. No texto principal, publicado mais especificamente na página sete do caderno de esportes, o primeiro fato relatado foi sobre a bela participação da torcida chinesa, que praticamente lotou o estádio para apreciar o futebol apresentado pelas seleções brasileira e americana, além de ver a melhor jogadora de futebol do mundo da época em ação, Marta. A preferência da torcida chinesa pela seleção brasileira foi exemplificada pela Gazeta com as seguintes palavras:

A cada vez que o ataque brasileiro tocava na bola, $o$ estádio gritava "Baxi! Baxi!" (Brasil em chinês) ou "Mata! Mata!", numa alusão a artilheira do mundial. Foi a forma como os chineses encontraram para reverenciar a goleada por 4 a 0 sobre as americanas, com direito a show da camisa 10 , nas semifinais do Mundial. (GAZETA DO POVO, 28 set. 2007, p.7 do caderno esportivo).

A notícia discorreu sobre fatos como a atuação impecável da seleção brasileira e o show de técnica e 
habilidade da camisa 10 do Brasil, que marcou dois dos quatro gols da seleção, que acabou vencendo o confronto por 4 a 0 . A imagem que ilustrava a matéria possuía a seguinte legenda "Marta à frente de Ellerton, vítima da habilidade da brasileira" (GAZETA DO POVO, 28 de set., 2007, p.7 do caderno esportivo). A matéria comentou também sobre a repercussão da derrota dos EUA nas revistas e jornais americanos, que resultou em várias críticas ao treinador da seleção americana, Greg Ryan, por ter optado em deixar no banco a atleta Hope Solo, que até então era a goleira titular dos EUA, mas, principalmente, quanto aos métodos utilizados pelo treinador, como se vê no seguinte excerto:

No site da revista Women's Soccer World, Ryan não foi poupado. Em tom quase editorial, a publicação critica os métodos do treinador e pede a federação norte-americana que indique uma mulher para treinar a equipe a partir de agora "A maioria dos times universitários tem treinadoras com mais conhecimento que Ryan", escreveu um articulista da revista. Um blogueiro de futebol da ESPN escreveu que Ryan, ao optar por Scurry no gol e deixar Solo no banco, usou método que podem funcionar no beisebol, porém que não funcionam no futebol (GAZETA DO POVO, 28 de set. 2007, p.7 do caderno esportivo).

É valido destacar a pressão colocada pela revista Women's Soccer World para que uma mulher fosse a treinadora da seleção feminina norte-america, situação esta que no Brasil nem é cogitada. Isso pode ser entendido como uma diferença de formação cultural da modalidade nos diferentes países, visto que no Brasil esse esporte se constituiu de maneira amplamente relacionada ao gênero masculino e no país norte-americano isso se deu de forma muito mais similar, com, inclusive, uma leve predominância às mulheres.

Viu-se, nas páginas que reportaram o jogo de semifinal brasileira na Gazeta do Povo, o reconhecimento do grande momento técnico pelo qual a seleção passava, caracterizando tal jogo como espetáculo e dando um grande espaço para repercutir seus desfechos. Por fim, imediatamente na mesma matéria começou a ser divulgada a grande final da competição, que seria realizada contra a seleção alemã.
Além da matéria do dia 28, até o dia 30 o confronto foi lembrado pelo jornal através de três pequenas notas no espaço "Programe-se" (uma em cada dia) e mais cinco textos foram publicados com o intuito de promover o jogo decisivo do mundial. Uma delas merece destaque: falando sobre o "velho discurso" de falta de apoio, o jornal fez uma análise sobre o papel da CBF na condução do futebol feminino, através da fala de algumas atletas com grande representatividade. Foi deixada clara a diferença de apoio e investimento dado pela CBF para o futebol masculino e o feminino, e o exemplo utilizado foi o uso de um uniforme antigo da seleção masculina pelas mulheres na disputa do Pan-americano de 2007. Com o burburinho que estava sendo causado e pela crescente legitimação das reclamações das atletas, devido a seus importantes resultados em competições internacionais, a CBF prometeu realizar uma Copa do Brasil feminina.

Apesar da ótima campanha e do entusiasmo exposto no caderno esportivo da Gazeta sobre a final da Copa do Mundo, as brasileiras não conseguiram vencer as alemãs no confronto decisivo, sendo derrotadas por 2 a 0 . Sobre isso, no dia $1^{\circ}$ de outubro, dia seguinte à partida, o caderno não economizou espaço para relatar os detalhes do jogo. Foram duas páginas de destaque e quatro matérias com abordagens diferentes. A primeira delas retomava o discurso da falta de apoio ao futebol feminino no Brasil. A segunda, com um pouco mais de detalhes, falava sobre a mobilização da família e da cidade de Dois Riachos, para assistir a grande final e torcer por Marta, jogadora natural da pequena cidade alagoana. A terceira descreveu o jogo e detalhes da partida, trazendo um título em tom de frustação "O dia em que a eficiência parou a arte" (GAZETA DO POVO, 28 de set. 2007, p.8 do caderno esportivo). A matéria colocou em evidência a atuação da goleira alemã e da camisa 10 do Brasil, que nesse jogo não manteve o ótimo desempenho que vinha tendo e inclusive perdeu um pênalti. A quarta e última nota se referia ao protesto que algumas jogadoras da seleção brasileira realizaram ao subir ao pódio carregando um cartaz que pedia apoio ao futebol feminino no Brasil. Notase que o jornal reiterou o protesto feito pelas atletas, comentando sobre as promessas antigas feitas pela $\mathrm{CBF}$ que não foram cumpridas. Esse posicionamento demonstra o interesse em transmitir ao público leitor 
o real cenário vivido pelo selecionado nacional, num contexto geral do futebol feminino no Brasil.

Após o término da competição, as críticas à CBF e exigências de incentivo e melhor estrutura para o futebol feminino brasileiro continuaram repercutindo na Gazeta do Povo:

A Seleção brasileira de futebol feminino, vicecampeã da Copa do Mundo, exigiu da CBF incentivo, premiação e estrutura durante o desembarque da delegação, ontem, no Rio. A equipe demonstrou desconfiança quanto as promessas da entidade em realizar a Copa do Brasil para as mulheres, prevista para começar em outubro. Várias atletas reclamaram do descaso do país. Contaram que a seleção viajou pra China sem cozinheiro e passou quase um mês sem comer feijão. Revelaram que sofreram com a alimentação inadequada. "Comemos coisas que não estávamos acostumadas", disse uma das jogadoras da equipe que pediu anonimato. A Seleção reivindica também mais amistosos durante o ano (GAZETA DO POVO, 3 out 2007, p.3).

Outro ponto abordado foi a dificuldade encontrada pela grande maioria das atletas, que ficou clara em publicações especiais que ocuparam duas páginas do caderno esportivo no dia 7 de outubro:

[...] O salário de 30 mil euros ( $\mathrm{R} \$ 77$ mil), pago religiosamente nos três primeiros dias do mês é quase uma utopia para quem não tem o mesmo talento - ou a oportunidade - da versão feminina de Ronaldinho Gaúcho (VICELLI, 7 out. 2007, p. 4).

Nesse trecho, o jornal comparou a melhor jogadora de futebol do mundo à época, Marta, com o melhor jogador de futebol do mundo em 2004 e 2005 , Ronaldinho Gaúcho, demonstrando a exorbitante diferença econômica que baliza a prática do futebol profissional masculino e feminino.

A dupla jornada vivida pela grande maioria das atletas também foi abordada por Vicelli, um dos redatores do caderno esportivo da Gazeta, em matéria publicada no dia 7 de outubro de 2007:

Fabíola Zanella, de 25 anos, divide seu tempo entre o trabalho, numa empresa de engenharia civil, o curso de educação física, os treinos no time de futsal da Faculdade Dom Bosco (responsável pela bolsa de estudos) (...) A baixa remuneração obrigou a jogadora deixar a bola em segundo plano e encarar uma longa jornada que quase nunca termina antes da meia noite. A falta de tempo para se dedicar ao futebol, fez com que a garota, convocada ano passado para um período de preparação da seleção brasileira na Granja Comary, em Teresópolis- RJ, não aguentasse o puxado ritmo de treinos diários. (VICELLI, 7 out. 2007, p.5).

Neste dia, quatro matérias foram publicadas com relação a esse tema. Nota-se, aqui, uma tentativa de aproximar o público leitor das notícias da seleção brasileira e da realidade vivida pelas atletas dos clubes locais de Curitiba, cidade principal de distribuição do periódico da Gazeta. Vicelli relatou a realidade vivida pelas atletas da equipe do Villa Fanny, clube amador tradicional de Curitiba. A reportagem trouxe dados como os míseros valores recebidos pelas atletas após cada jogo, a dificuldade para treinar durante a semana, devido ao fato de que praticamente todas precisam trabalhar para se manter estáveis financeiramente, além da precariedade das estruturas oferecidas pelo clube, como vestiários sujos, falta de iluminação no campo, poucas bolas e materiais para treinamento.

A última matéria publicada na Gazeta do Povo no ano de 2007 (em 12 de outubro) - que pode ser considerada uma consequência da boa campanha da seleção brasileira na Copa do Mundo daquele ano fazia referência ao projeto Futebol Mulher, lançado pela empresa Cocco Sport Marketing, logo após a CBF anunciar a criação da Copa do Brasil. O projeto previa a formulação de um campeonato nacional nos moldes da NBA (famosa liga americana de basquetebol). Tudo isso parece apenas ser mais um daqueles efeitos imediatos que logo caem no esquecimento, já que a maioria das promessas não foi concretizada, e mais de oito anos depois, a situação do futebol feminino no país continua muito similar à época referida.

\section{A COPA DO MUNDO DE 2015: O RETRATO DA GAZETA DO POVO}

No ano de 2015, a Copa do Mundo de futebol feminino foi sediada no Canadá e a competição aconteceu entre os dias 6 de junho 5 de julho. $\mathrm{O}$ período utilizado para a coleta de dados corresponde ao mês anterior à realização da competição, ao mês em que a mesma ocorreu e ao mês seguinte, ou seja, maio, junho e julho de 2015 .

Nesse período foi encontrado um total de oito (8) matérias sobre o mundial no caderno de esportes da Gazeta do Povo, sendo que nenhuma delas constava 
como chamada na capa do jornal. Os jogos apareceram oito vezes nos "Destaques da TV" - nota em forma de um pequeno quadro que informam horários e canais nos quais importantes eventos esportivos irão ser transmitidos no presente dia.

No mês de maio, não foi encontrada nenhuma notícia sobre o mundial de futebol feminino nas páginas do periódico. Já em junho, mês da realização do evento, foram encontradas seis matérias. Sendo uma única matéria publicada no mês de julho.

A primeira matéria encontrada foi publicada no dia 9 de junho. Nessa data, o caderno esportivo trouxe duas notas sobre o mundial - único dia em que isso aconteceu. A primeira, com o título "Largada" (GAZETA DO POVO, 9 jun. 2015, p.2 do caderno esportivo), dentro do espaço destinado aos "Destaques da TV". Esta foi formatada em um pequeno espaço do caderno esportivo do periódico e chamava a atenção para a estreia do "time do técnico Vadão" no Mundial do Canadá. Percebe-se aqui uma tentativa de aproximar a seleção brasileira feminina de um aspecto mais comum aos olhos do público, ou seja, fazendo referência ao técnico Vadão, profissional com ampla circulação no ambiente do futebol masculino no Brasil, a chamada procura dar maior representatividade ao selecionado nacional. Logo em seguida, no mesmo caderno esportivo, vê-se o título "Brasil estreia contra a Coréia do Sul no Mundial do Canadá" e a chamada para o início da trajetória brasileira reforça o seguinte:

Mais uma vez a maior esperança do Brasil está no trio formado por Marta, Formiga e Cristiane. Treinada por Oswaldo Alvarez, a seleção luta por seu primeiro título - foi vice na China, em 2007, e terceira colocada nos Estados Unidos em 1999. O trio de "veteranas" tem o respeito das outras jogadoras da seleção. "Cada jogadora tem a sua responsabilidade dentro de uma equipe, mas quando você é a capitã é totalmente diferente. Hoje, dentro de campo, olho para um lado e vejo a Formiga, para outro vejo Marta e Cristiane", disse Andressinha, de 20 anos, que jogará o primeiro Mundial com a seleção principal. Espanha e Costa Rica fecham o grupo do Brasil na primeira fase do mundial. (Gazeta do povo, 9 jun. 2015, p.2 do caderno esportivo).

Às vésperas da estreia do torneio mais importante do circuito mundial de futebol feminino, as matérias destinadas ao primeiro jogo da seleção brasileira não foram ilustradas por imagens, muitos menos contaram com informações detalhadas sobre a escalação ou aspectos táticos do confronto. Pelo contrário, limitaram-se a falar da conhecida importância de atletas consagradas, as três veteranas da seleção brasileira (Marta, Formiga e Cristiane).

No dia seguinte, 10 de junho, foi publicada na página dois do caderno esportivo a seguinte matéria: "Marta alcança recorde de gols na estreia do mundial". O destaque é dado para o recorde de gols alcançado pela jogadora brasileira, que se tornou a atleta que mais marcou em todas as edições da Copa do Mundo de Futebol feminino. A matéria apresenta um resumo dos lances que resultaram em gols, sem entrar no mérito de beleza e/ ou feminilidade. Apesar de ainda ter pouco destaque no jornal, a matéria conta com imagens para ilustrar seu conteúdo, o que por si só já é um fator de diferenciação, já que as demais, em sua maioria, não possuíam ilustrações.

Imagem 1 - Reportagem dia 10 de junho de 2015

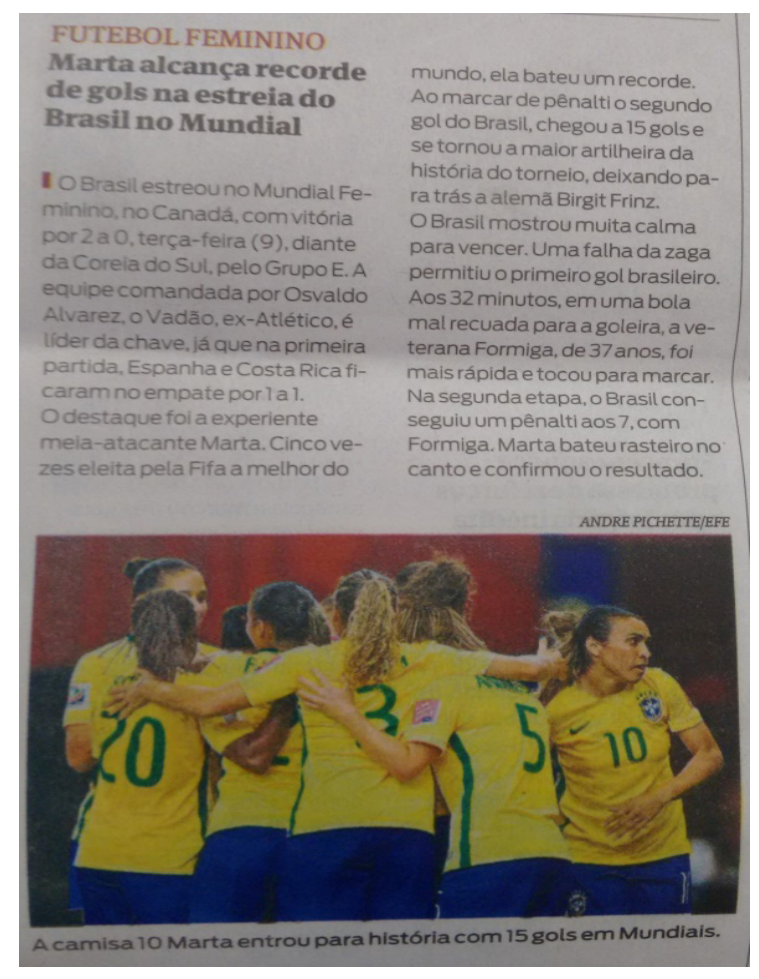

GAZETA DO POVO, Marta alcança recorde de gols na estreia do Brasil no Mundial, 10 de jun. 2015, p.2 do caderno esportivo.

A matéria do dia 14 de junho, sobre a vitória de seleção brasileira feminina sobre a Espanha, que garantiu a classificação para as oitavas de final do 
Mundial, divide a página com a reportagem publicada sobre o jogo entre Paraguai e Argentina pela Copa América de futebol masculino. Essa divisão foi feita de forma desigual, ou seja, há uma clara preferência por noticiar o jogo entre duas seleções masculinas a reportar a conquista da vaga para as oitavas-de-finais da seleção feminina, já que a reportagem destinada a contar a história do jogo masculino ocupa quase a totalidade da página.

A matéria sobre o jogo entre Brasil e Costa Rica não contou com nenhuma imagem para ilustração. $\mathrm{O}$ conteúdo deu destaque para a tranquilidade com que as brasileiras chegaram ao último confronto da fase de grupos, já que, tendo vencido os demais jogos, a seleção teve o privilégio de poupar as titulares e dar espaço para as jogadoras reservas, que venceram a partida por $1 \mathrm{x} 0$ e garantiram $100 \%$ de aproveitamento nessa fase. É válido comentar que, na mesma página na qual essa reportagem foi publicada, também foi vinculada uma matéria da derrota da seleção masculina de futebol para a Colômbia na Copa América; matéria esta que recebeu uma imagem ilustrativa que ocupava praticamente metade da página seis do caderno esportivo. Tal fato nos faz retomar ao já citado potencial de retorno, que é mais representado em matérias relacionadas ao futebol masculino, pois como se sabe este representa um forte fator na constituição da identidade nacional brasileira, o que faz inclusive com que uma notícia sobre um campeonato continental se sobreponha ao mundial feminino. Isso também pode ser entendido pela predominância de público masculino que, historicamente, adquire periódicos impressos.

A matéria sobre o jogo das oitavas de final, Brasil x Austrália, teve pouco destaque no jornal analisado, ocupando aproximadamente um espaço de 4x3 cm. Publicada no dia 21 de junho, com o título "Seleção feminina busca vaga nas quartas", tal notícia foi elaborada para promover a disputa de um jogo eliminatório de uma copa do mundo após uma campanha com $100 \%$ de aproveitamento na primeira fase da competição, o que deu ao Brasil o posto de melhor colocado geral. A publicação divide espaço na página quatro do caderno esportivo do periódico, com uma detalhada matéria sobre a ausência de Neymar na disputa do próximo jogo na Copa América de futebol masculino. Oposição que reflete, também, a diferença de relevância dada as duas modalidades no imaginário social.

A maior matéria da Gazeta do Povo sobre o mundial feminino de 2015, foi publicada no dia seguinte:

Imagem 2 - Reportagem do dia 22 de junho de 2015

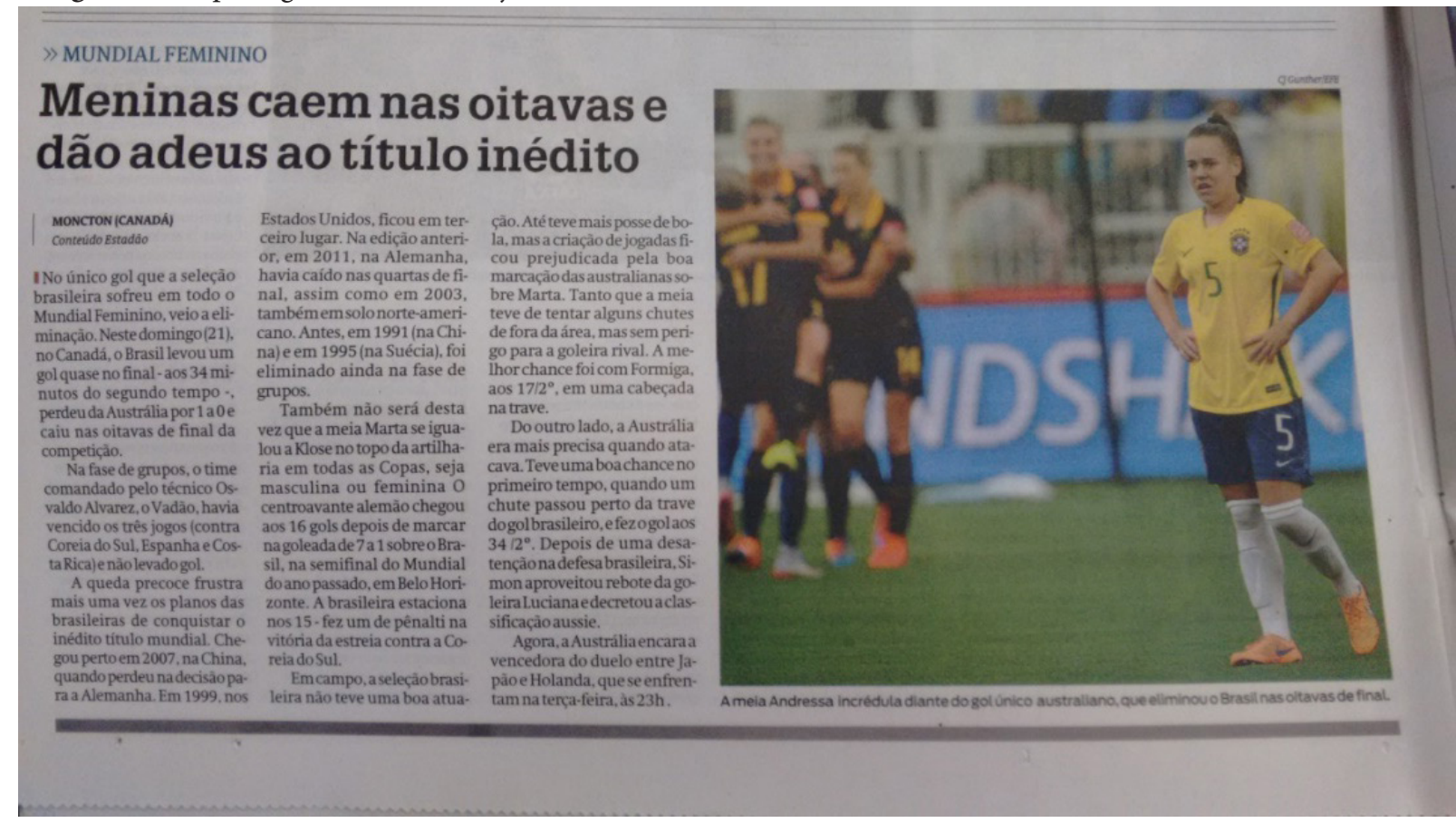

GAZETA DO POVO, Meninas caem nas oitavas e dão adeus ao título inédito, 22 de jun. 2015, p.6 do caderno esportivo. 
A reportagem, divulgada no dia 22 de junho, na página seis (6) do caderno esportivo, faz referência à derrota da seleção brasileira nas oitavas de final da competição, diante da seleção australiana, notícia que ocupou aproximadamente $1 / 3$ da referida página do caderno esportivo. Além da matéria do dia 10 de junho, esta foi a única a receber uma imagem sobre a campanha brasileira na competição. Sobre o conteúdo, foi salientado o fato de que o único gol tomado pela seleção brasileira no mundial resultou em sua eliminação. Na mesma página, ocupando o restante do espaço, foi publicada uma matéria com a seguinte chamada "Brasil supera a ausência de Neymar" (GAZETA DO POVO, 22 jun. 2015, p.6 do caderno esportivo), tratando da vitória da seleção masculina na Copa América, por 2x1 sobre a Venezuela. A matéria sobre a seleção masculina, além de conter uma grande foto sobre o jogo, possui também uma ilustração sobre os próximos cruzamentos e uma tabela detalhada sobre quais jogadores foram utilizados durante a partida. Reportagem que inclusive possuía chamada na capa do jornal. Aqui evidencia-se a influência dos fatores de consumo mencionados anteriormente, os quais pautam o destaque e a importância dados a determinado assunto nos meios de comunicação. Ou seja, o periódico considera mais pertinente e lucrativo noticiar de forma mais completa e abrangente os jogos da seleção masculina de futebol, independentemente dos resultados obtidos, já que o potencial de retorno dessa modalidade é maior se comparado ao seu correspondente feminino.

Após a matéria sobre a eliminação das brasileiras no mundial, a próxima e última matéria encontrada foi publicada no dia 6 de julho, matéria esta que tratava do desfecho da final da Copa do Mundo de Futebol Feminino. Na derradeira notícia sobre o campeonato mundial do Canadá, num pequeno espaço da página três do caderno esportivo, o qual possuía o mesmo tamanho da notícia sobre o empate entre Londrina e Guaratinguetá, em 0x0 pela série $\mathrm{C}$ do campeonato brasileiro, o jornal informou aos leitores sobre o vencedor do mundial, os EUA, sem falar de aspectos técnicos ou táticos utilizados pelas seleções. Neste momento, foi ressaltado o espetáculo apresentado pela seleção americana e a ampla vantagem que estas conquistaram no placar, que terminou em $5 \times 2$ sobre as nipônicas.

\section{CONSIDERAÇÕES FINAIS}

Depois de realizadas as análises do periódico Gazeta do Povo, foi constatado que, tanto em 2007 quanto em 2015, o jornal não realizou uma cobertura que promovesse a Copa do Mundo de futebol feminino, já que durante o mês antecedente aos dois torneios, nenhuma matéria relacionada ao assunto foi veiculada. Além disso, mesmo durante a realização dessas competições, nenhuma chamada foi publicada na capa do periódico.

Assim como constatou Bruno José Gabriel (2015), a respeito da cobertura jornalística feita pela Folha de São Paulo em relação às copas do mundo de futebol feminino, o presente trabalho também identificou não haver caráter depreciativo ou preconceituoso com relação à prática desse esporte pelas mulheres nas folhas do caderno esportivo do jornal Gazeta do Povo, ao reportar as copas do mundo de 2007 e 2015. Além disso, não houve um foco estético presente nas análises do periódico em relação às atletas da seleção. Indicando que, provavelmente, aquela visão anterior que pautava a prática feminina no futebol (SALVINI; MARCHI JUNIOR, 2013 e 2013a; MOURÃO; MOREL, 2005), já foi bastante relativizada.

Outra importante conclusão é que houve uma disparidade muito grande de quantidade de matérias publicadas no ano de 2007 com relação a 2015, já que naquele ano foram publicadas vinte e oito (28) matérias e neste, o número foi reduzido a somente oito (8).

Alguns aspectos podem ser levados em consideração para tamanha diferença. Primeiramente, no ano de 2007, pouco antes da realização do campeonato mundial, as brasileiras haviam sido campeãs Pan-americanas, jogando em território brasileiro e derrotando na final a fortíssima seleção estadunidense. Dessa forma, a seleção entrava em um breve momento de visibilidade, inclusive com reclamações e reivindicações públicas com relação ao apoio necessário à modalidade no país. Já no ano de 2015, a seleção brasileira também foi campeã Panamericana de futebol feminino, mas, essa competição aconteceu após o mundial. Elemento que, somado aos resultados pouco significativos em competições anteriores, (no Mundial de 2011 as brasileiras foram eliminadas nas quartas-de-final e no Pan de 2011, 
as brasileiras perderam a final para as canadenses, ficando com a segunda colocação), acabou por não legitimar qualquer expectativa em termos de bons resultados por parte da seleção feminina.

Esse fato demonstra que o aparecimento do futebol feminino na mídia segue um padrão de descontinuidade, já que isso geralmente ocorre apenas em períodos específicos durante a realização de competições importantes e ainda depende de bons resultados da seleção brasileira para uma vinculação maior de notícias correlacionadas. Isso pode ser observado no tratamento dado pelo jornal à campanha da seleção na Copa do Mundo de 2007, visto que nessa oportunidade a equipe chegou até a final da competição e pareceu dessa forma legitimar-se para reivindicar melhores condições para sua prática fato repercutido em várias matérias posteriores ao encerramento do mundial. Pelo contrário, a Copa do Mundo de 2015 (na qual a seleção foi derrotada nas oitavas-de-finais) possuiu uma cobertura bem menor nas páginas do periódico e esta se iniciou e teve encerramento durante a exata duração da competição.

\section{REFERÊNCIAS}

BOURDIEU, P. Questões de sociologia. Rio de Janeiro: Marco Zero, 1983.

FONTES JUNIOR, M. Copa do Mundo de Futebol Feminino: 1991, o início de tudo. 16 maio 2015. Disponível em: $\quad<\mathrm{http}: / /$ torcedores.com/noticias/2015/05/copa-domundo-de-futebol-feminino-1991-o-inicio-de-tudo $>$. Acesso em 5 nov. 2015.

GABRIEL, J. G. A cobertura acerca da seleção brasileira de futebol feminino realizada pelo caderno de esporte da Folha de S. Paulo (1991 - 2011), Dissertação (Mestrado em Ciências Sociais Aplicadas), Universidade Estadual de Ponta Grossa. 252p. Ponta Grossa, 2015.

GAZETA DO POVO. Marta comanda o Brasil na luta pelo mundial. 11 set. 2007, p. 2 do caderno esportivo.

Programe-se. 12 set. 2007, p.2 Caderno esportivo.

"Capitulo mais bonito" move as brasileiras. 23 set. 2007, p.5 do Caderno esportivo.

. Americanas elogiam Marta. 26 set. 2007, p.2 Caderno esportivo.

O dia em que a eficiência parou a arte. 1 out. 2007, p.8 Caderno esportivo.

Seleção reclama da falta de feijão estrutura e premiações. 3 out. 2007, p.3 do Caderno esportivo.
. Largada. 9 de jun. 2015, p.2 do Caderno esportivo.

Marta alcança recorde de gols na estreia do Brasil no Mundial. 10 de jun. 2015, p.2 do Caderno esportivo.

Meninas caem nas oitavas e dão adeus ao título inédito. 22 de jun. 2015, p.6 do Caderno esportivo.

. Brasil supera a ausência de Neymar. 22 jun. 2015, p.6 Caderno esportivo.

GOELLNER, S. V. Mulheres e futebol no Brasil: entre sombras e visibilidades. Revista brasileira de Educação Física e Esportes, São Paulo: v. 19, n. 02, p. 143-151, abr./ jun. 2005.

LUCA, T. R. Historia dos, nos e por meio dos periódicos. In: PINSKY, Carla Bassanezi (Org). Fontes Históricas. São Paulo: Contexto, p. 111-153. 2008.

MOLLER. Intacto, Brasil avança na copa. Gazeta do povo. 21 set. 2007, p.3 do Caderno esportivo.

MOURÃO, L.; MOREL, M. As narrativas sobre o futebol feminino: o discurso da mídia impressa em campo. Rev. Bras. Ciên. Esporte, Campinas, v. 26, n. 2, p. 73-86, jan. 2005.

SALVINI, L. ; MARCHI JUNIOR, W. . Uma História Do Futebol Feminino Nas Páginas Da Revista Placar Entre Os Anos De 1980 e 1990. Movimento (Porto Alegre. Online), v. 19, p. 95-115, 2013.

Notoriedade Mundial E Visibilidade Local: O

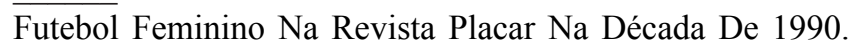
Revistas Sociologias Plurais, v. 1, p. 144-160, 2013a.

SILVA, L. L. A história da Copa do Mundo de Futebol Feminino. 02 jun 2015. Disponível em: $<$ http://www. futeboleuropeu.com.br/2015/06/historia-da-copa-domundo-de-futebol-feminino.html>. Acesso em 05 nov. 2015.

VICELLI, C.E. Boleiras driblam a escuridão. Gazeta do Povo. 7 out. 2007, p.4-5 do Caderno esportivo.

WISNIK, J. M. Veneno Remédio - o Futebol e o Brasil. São Paulo: Companhia das Letras, 2008, p 345. 